\title{
Sustainability through the tourism entrepreneurship journey: A gender perspective
}

\section{ABSTRACT}

Women's tourism entrepreneurship has been identified as fundamental to meeting the UN's Sustainable Development Goals of both 'gender equality' and 'decent growth and economic growth' but neither entrepreneurship nor sustainability are gender neutral in the tourism industry. Therefore, further research is required into how gender influences sustainable entrepreneurship, providing insights for tourism entrepreneurship policy. In response to a prevalent essentialism in much of the literature, this paper adopts a post-structuralist framework, alongside a mixed-methods approach, to understand the complex role of gender and sustainability at different stages of entrepreneurship. The initial focus is on a survey of 539 tourism students (women and men) which analyses the latent and nascent entrepreneurship stages, while 19 interviews with established tourism entrepreneurs provide further insights into these issues. The analysis focusses especially on the individual characteristics of risk, personal attitudes to entrepreneurship and behavioural control. While broad gender differences are observed, notably in societal perceptions of risk aversion, there is also considerable blurring of the approaches of established entrepreneurs in particular to sustainability and entrepreneurship. If entrepreneurship is to enhance sustainability, policy needs to account for the non-essentialised gendered dimensions that inhibit and enable sustainable tourism entrepreneurship.

KEYWORDS: gender, sustainable entrepreneurship, post-structuralism, risk, mixed methods

\section{INTRODUCTION}

Women's entrepreneurship in the tourism industry has been identified as fundamental to meeting the UN's Sustainable Development Goals of both 'gender equality' and 'decent growth and economic growth' (UN World Tourism Organization (UNWTO, 2019). Yet research on this topic remains limited despite consensus among researchers about the complex role that gender plays in the different phases of the entrepreneurial process (i.e. pre-start up, start up and growth), as well as in entrepreneurial performance (Figueroa-Domecq, de Jong \& Williams, 2020; Ahl \& Marlow, 2019; Gupta et al. 2009; Minniti et al. 2005). Fundamentally, women are perceived to have less human capital and tend to perceive themselves as less competent in terms of entrepreneurial behaviour (Ploum et al. 2018), reflecting deep gender inequalities in power and status that have become engrained in society and accepted as 'normal and inevitable' (Ahl, 2006; Ahl \& Marlow, 2012). Furthermore, the tendency in the entrepreneurship literature to position masculinity as the norm when describing entrepreneurial traits, or using masculine characteristics to describe entrepreneurs, tends to make women invisible and inconspicuous (Marlow \& Patton, 2005). There is, therefore, a considerable gap between the aspirations of the UN Sustainable Development Goals and the gendered dimensions of entrepreneurship. This is compounded by the highly gendered nature of sustainability in the working environment (Hesselbarth \& Schaltegger, 2014; Ploum et al. 2018). Women working for sustainable development individually, and 
as members of civil society, play a key role in supporting their communities (Global Volunteers, 2019; UN Women, 2014; UNWTO, 2019) and are generally more socially oriented than men when operating businesses (Betz et al. 1989).

Bringing together the gender and sustainability perspectives indicates the need to understand gendered attitudes towards, and experiences of, the increasing business commitment to more sustainable entrepreneurship (Zahra et al. 2014). In short, how is sustainable entrepreneurship gendered? This question has largely been neglected by tourism scholars who have tended to focus on the barriers encountered by women entrepreneurs that is, on enhancing economic sustainability, whilst ignoring the social and environmental dimensions of entrepreneurship. This neglect is surprising because tourism has been acknowledged as a fertile field for entrepreneurial initiatives, due to a predominance of small firms and relatively low entry barriers (Nikraftar \& Hosseini, 2016; Li, 2008; Shaw \& Williams, 1999), while tourism's diverse, dynamic and flexible nature (Peeters \& Ateljevic, 2008) has led to it being perceived as a potentially empowering sector for women entrepreneurs (UNWTO, 2019; Vujko et al. 2019). Additionally, it is contended that, in the long term, tourism cannot survive if it is not both sustainable and entrepreneurial (Crnogaj et al. 2014:377) and, as indicated, these are both gendered.

Consequently, this article aims to explore the application of a gender perspective to understanding the importance given to sustainability in tourism entrepreneurship. This will provide perspectives on how sustainable entrepreneurship and sustainability in entrepreneurship are gendered. In addressing this aim, we adopt a post-structuralist approach, which recognises the limitations of structuralism, particularly its essentialism. Following on from this, our analysis focusses especially on risk, attitudes to entrepreneurship, and behavioural control as providing non-essentialist insights into the gendered nature of sustainable entrepreneurship. Given that entrepreneurialism is an individualised, complex journey, the need to avoid oversimplified generalizations becomes even greater: different influences shape the varied experiences of women and men over the journey.

A mixed method approach is adopted to studying the entrepreneurship journey, drawing on findings from Spain. More specifically, this study proposes a Quantitative Dominant (QUANT-qual) concurrent complementary method design (Truong, Liu \& Yu, 2020): QUANT through a survey of latent and nascent entrepreneurs among tourism students in Spain (539), and the impact of sustainability on their entrepreneurial ideas and steps (Study A); and Qual through interviews with 19 established entrepreneurs about their nuanced entrepreneurial experience and the varied importance placed on sustainability (Study B). This design emphasises the complementarity of the results (Truong, Liu \& Yu, 2020; Dayour et al. 2019) from the survey among students (QUANT), with the reflections of a group of established entrepreneurs (qual) providing further insights into complexity and greater nuance.

\section{LITERATURE REVIEW \& THEORETICAL FRAMEWORK}

Sustainability is a holistic and integrated approach that considers ecological, social and economic dimensions, recognizing that all three must be considered together to find lasting prosperity. It demands ways of living, working and being that enables all human beings to lead healthy, fulfilling, and 
economically secure lives while reducing pressure on the environment and not endangering the welfare of future generations (Santillo, 2007) Sustainability is seen as factor of success in the working environment and it is increasingly integrated into business processes (Ploum et al. 2018).

Sustainable entrepreneurship is defined in this paper as the recognition, establishment, assessment and exploitation of entrepreneurial opportunities that enable the production of goods and services that contribute to profitability and sustainability of a firm whilst directly and indirectly engendering positive social and environmental impacts for community and its members (Shepherd \& Patzelt, 2011). Sustainable entrepreneurship in the tourism sector broadly fits this definition, yet also incorporates a more holistic emphasis (Crnogaj et al. 2014) on the destination scale, alongside the individual and organizational. The literature review first sets out the rationale for considering how attitudes, behavioural control and risk provide a means to look beyond the inherent essentialism of focusing on socio-economic, socio-demographic and institutional considerations. It then considers the value of a post structuralist approach.

\subsection{SUSTAINABLE ENTREPRENEURSHIP, GENDER AND TOURISM}

Entrepreneurship is highly gendered and the relevance of sustainability to entrepreneurs, employees and consumers, is also considered to be gendered. It has been argued that women play a stronger role than men in establishing positive values in terms of social welfare, family and community wellbeing (Kimbu \& Ngoasong, 2016), reducing carbon emissions and greenhouse gases (De Silva \& Pownall, 2014). Relatedly, firms characterized by gender diverse leadership teams/boards tend to be more effective at pursuing environmentally friendly strategies and have more enhanced sustainability reporting mechanisms (Kasinis et al. 2016). Although this is questioned in some studies (e.g. Glass et al. 2015), the literature generally suggests that women tend to demonstrate a more environmentally conscious responsible attitude than men as entrepreneurs.

In tourism research, Braun's (2010) analysis of attitudes and behaviour towards sustainability among Australian businesses surmised that, women's desire to make their enterprises more sustainable/greener was overwhelmingly motivated by broader ethical concerns. Similarly, Polk's (2003) survey of sustainable transportation systems in Sweden concluded that women were more prepared than men to participate in ecologically benign activities and were consistently more supportive of ecological issues. This is because, as Scheyvens (2000) argues, women develop different knowledge of the environment while their roles within their families and communities often place them in close connection with the natural environment. However, the relationship between gender, sustainability and tourism entrepreneurship is largely unexplored with very few exceptions (see e.g. Kokkranikal \& Morrison, 2002; Thompson et al. 2018; Dahles et al. 2020). In particular, the explicit role of gender as a moderating variable/influence for nascent and extant entrepreneurs to engage in sustainable entrepreneurship (Outsios \& Farooqi, 2017) has not been explored.

In terms of the determinants of these different levels of interest, the social and environmental contexts are of course important. For example, societal obligations manifested, in family commitments and other 
caring responsibilities are often ascribed to women (Ngoasong \& Kimbu, 2019; Kimbu \& Ngoasong, 2016). Marlow (1997) contends that many women go into entrepreneurship and self-employment as a result of balancing family commitments and work. That is, the conditional flexibility conferred by selfemployment and entrepreneurship is strongly associated with female (sustainable) entrepreneurs (Outsios \& Farooqi 2017). In summary, within tourism, societal demands impact on women's time commitment and ability to acquire and/or improve the skills needed to grow their businesses and engage in more sustainable activities (Moreno-Alarcón \& Cole, 2019; Roomi et al. 2009).

These broad structural considerations do not explain the considerable variation in individual women's experiences of sustainable entrepreneurship. Looking beyond societal norms and expectations (Koe et al. 2014), sustainable entrepreneurs need to perceive entrepreneurship as desirable, have positive perceptions of their capabilities, self-confidence and aspire to be one's own boss (Koe et al. 2014). They also need to be prepared to take risks (Greco \& de Jong, 2017) which, although gendered, do not follow any simple gender divisions. The remainder of the literature review considers personal attitude towards sustainable entrepreneurship, behavioural control and risk: these have been little researched in general, and not at all in tourism, in relation to gender and the entrepreneurial journey.

\subsection{PERSONAL ATTITUDE TOWARDS ENTREPRENEURSHIP (PAE)}

The entrepreneurial journey begins with potential entrepreneurs who believe they have the necessary skills, can perceive business opportunities, and wish to exploit these. In contrast, sustainable entrepreneurship also takes into account environmental and societal goals (Cohen \& Winn, 2007; Dean \& McMullen, 2007; Crnogaj et al. 2014: 378.)

Personal attitudes are important in engaging with sustainable entrepreneurship and these are gendered. Men tend to be more interested in entrepreneurship, and "a significant portion of the gender gap in entrepreneurial propensity is explained by subjective perceptions whereas socio-economic variables appear to play a smaller role" (Koellinger et al. 2013, pp. 229). Perceptual factors are ergo crucial in explaining how gender differences influence PAE, and how these impact attitudes towards sustainability and enterprise performance. However, a cautious and reflective approach towards business growth and engagement in sustainability is not limited to women. Outsios \& Faroogi (2017) note that there is no gendered difference in the attitude and desire of entrepreneurs to growing their businesses; instead, both men and women manifested a positive desire to grow their enterprises but were wary of the impact on the environment and the sustainability of their businesses. This cautiousness stems from ethical issues in dealing with the (in)congruity between sustainability and growth of their businesses as well as the community support they provide (Hallak et al. 2013), rather than gendered perceptions about family commitments, or their roles in business and society. Irrespective of gender, consideration should be given to ethical and strategic challenges that are encountered as a business grows whilst ensuring it remains sustainable.

\subsection{BEHAVIOURAL CONTROL (BC)}


Bamberg \& Möser (2007) identified BC, alongside attitudes and personal norms, as essential in driving (sustainable) behaviour. Individuals with a favourable attitude towards a behaviour perceive it as producing desirable outcomes or eliciting positive emotions when manifested (Kraft et al. 2005). Additionally, Ajzen (2002) notes that an individual's belief that they have a high probability to behave in a particular way successfully, as well as persistence in adopting that behaviour, indicates a high perceived BC. Such individuals often take personal responsibility for addressing 'a problem' (De Groot \& Steg, 2009). Individuals with favourable attitudes, perceived supportive social norms, perceived behavioural control, and strong personal norms are more inclined to perform, behave and relate to others in a particular way. This is important for tourism entrepreneurs for whom networks (social and professional) are crucial in enabling the sustainability of their businesses, through access to capital and market opportunities (e.g. Ngoasong \& Kimbu 2016; 2019), knowledge and other resources, as well as hedging against risks and uncertainties (Williams et al. 2020); these networks are strongly gendered especially amongst nascent entrepreneurs (Braun, 2010).

From a gender perspective, tourism entrepreneurship studies have mainly examined issues such as women's agency in challenging gender roles, employment, empowerment and emancipation (Duffy et al. 2015; Ngoasong \& Kimbu, 2019), women transitioning from corporate jobs to entrepreneurship (Mattis, 2004), and women intrapreneurship (Zhang et al., 2020). In contrast, they have tended to ignore the influence of behaviour although certain pro-environmental behaviours - including BC - are largely driven by internal personal attributes.

\subsection{RISK}

Several studies (see e.g. Williams et al. 2020, Williams \& Baláž 2015, Hall \& Williams, 2019; Zhang et al., 2020) have explored the influence of risk and uncertainty in tourism entrepreneurship and innovation. In the most detailed study to date, Williams et al. (2020) note that dynamic capabilities determine entrepreneurs' ability to engage effectively with, and manage, the shifting risks and uncertainties their businesses encounter. Furthermore, the relationship between sustainable entrepreneurship and risk arises since this kind of entrepreneurial philosophy can confer opportunities that are sometimes observed in market failures and/or uncertain environments which detract from sustainability, including those that are environmentally relevant (Dean \& McMullen, 2007; Ateljevic \& Doorne, 2000).

But risk is multifaceted and influences entrepreneurship from different angles. Researchers have postulated that cognitive perception makes a significant contribution to the study of entrepreneurship, and risk is inherent to this (Barbosa et al. 2007). In this regard, according to Ajzen's (1991) Theory of Planned Behavior, attitudes, subjective norms and perceived behavioral control determine entrepreneurial intentions. At the same time, entrepreneurs' risk perceptions impact on their attitudes towards the control of events (Behavioral Control) (Keh, Der Foo \& Lim 2002).

Surprisingly, a gender lens is largely absent from this and other studies despite considerable extant evidence that gender variations in approaches to risk are the outcome of divergences in cognitive 
abilities and in how men and women assemble and process information and solve problems (Barrett,1995; Chung,1998). Women, it has been argued (e.g. Barber \& Odean, 2001; Rowe \& Wright, 2001), tend to be more risk averse than men, which Kepler \& Shane (2007) attribute to their "caring and nurturing" role, reinforcing stereotypical norms. This may influence engagement with crises: for example, Carlsson-Kanyama et al. (2010) in their study of climate-change related risk judgements demonstrated that women, more than men, felt a responsibility to act to limit climate change (being more risk averse).

Sexton and Bowman-Upton (1990) note that women entrepreneurs are more risk averse than men entrepreneurs and consequently, dedicate more time searching for information on how to reduce potential risk and uncertainties. They are also less inclined to forgo potential benefits as they have a greater fear of failure (Camelo-Ordaz et al. 2016), are more loss averse, and more likely to engage in businesses with lower probability of failure and profit (Brush et al, 2009).

Women's risk aversion propensity is also manifested when accessing finance. Raising capital, and managing finance and debt, whether in the start-up or expansion/growth phases, is fraught with risks and uncertainties for both men and women (e.g. Kassinis et al. 2016). However, women owners of sustainable SMEs are more reluctant to take on debt due to concerns about how this will impact on their goals (Outsios \& Farooqi, 2017). Instead, they are more likely than men to rely on personal savings, family and friends networks, and/or ploughing back profits into the businesses (Kassinis et al. 2016; Ngoasong \& Kimbu, 2019). Marlow and Swail (2014) and Zhang et al (2020) surmise that women are often positioned as a group that is structurally marginalised and lacking the masculine attributes often mirrored in the normative male entrepreneurial model due to how researchers portray women as "risk averse", coupled with prior experiences, gender socialisation, and cognitive cues.

While PAE, BC and risk significantly broaden, and complicate, our understanding of the gendering of sustainable entrepreneurship, the challenge of essentialising gender differences remains highly germane. We seek to address this via a post structuralist approach.

\subsection{A POST-STRUCTURALIST THEORETICAL FRAMEWORK}

Western feminists have become increasingly engaged with environmental issues and theories since the 1980s (Goebe, 2003). Fundamental to early conceptualisations was the association thought to exist between women and the environment - whereby women were recognised as possessing a form of privileged epistemological understanding of nature compared to men. Women and nature were perceived as being innately interconnected, driven by patriarchal power relations that intersect with other inequalities (such as, culture and class) (Wachholz, 2011: 289). This conceptualisation rendered 'women' as a homogenous, essentialised category, who tended to be characterized by victimhood in inequitable gender systems, and environmental contexts of deterioration (Goebel, 2003). An underlying thread was the premise that Western capitalism was the cause of environmental destruction, and that Westernised ideas were thus incapable in responding to environmental concerns, in contrast to indigenous approaches and ways of living. 
Whilst feminists have engaged in deconstructing innate relations between women and the environment since the 1990s, broader tourism management scholarship has consistently identified 'women' as having higher concern and awareness of the environment, compared to 'men' (cf. Betz et al. 2013; Kato 2019; Kimbu \& Ngaosong 2016; Scheyvens 2000). There is therefore tension within tourism scholarship regarding how to understand gendered relationships to sustainability and the implications for tourism management. There has been particular interest in the role of tourism entrepreneurs as offering insights into the ways tourism and sustainability are conceptualised at the individual scale, by those negotiating everyday choices regarding sustainability (Outsios \& Farooqi 2017).

A post structuralist approach helps to address the complexity of entrepreneurial performance by focusing on how the intersectionality of identity (including gender, age nationality, etc.) shapes the varying pathways of tourism entrepreneurship and informs perceptions and performances relating to sustainability within entrepreneurial journeys. A post structuralist approach allows entrepreneurship to be understood as a complex, multi-layered activity where shifts in ideas occur in different social interactive systems. A detailed analysis of the varying experiences of gendered entrepreneurship allows the identification of what is often made invisible in more 'traditional', structuralist models, whilst also questioning internal bias within the literature that seeks to construct 'sustainability' as an essentialised and fixed category (Kato 2019). In summary, this paper undertakes a feminist analysis of tourism entrepreneurship and sustainability, drawing on post structuralism to deconstruct the tensions and complexities constituting gender and sustainability.

Sustainable entrepreneurship also needs to be viewed not as an outcome but as a journey, with different stages. Whilst recognising the limitations to generalization, three main phases tend to be identified in the entrepreneurial journey: latent entrepreneurs, with preferences for self-employment; nascent entrepreneurs already taking steps to start a business; entrepreneurs in new businesses and subsequent consolidation and growth phases (Bönte \& Piegeler, 2013; Global Entrepreneurship Monitor, 2019). Post structuralism reminds us these phases are not necessarily uni-linear. Whether and how the relationship between gender, entrepreneurship and sustainability shift across these stages remains largely under-researched.

\section{METHODOLOGY}

The division of research into the dichotomy of quantitative and qualitative approaches is debatable and viewed by some scholars as "neither meaningful nor productive" (Shah et al., 2018, p. 91). Consequently, mixed methods have become a third major research paradigm (Creswell \& Creswell, 2018) and is increasingly applied in tourism research (Truong, Liu \& Yu, 2020; Dayour et al. 2019).

This study adopts a quantitative dominant mixed methods approach informed by the need to follow latent, nascent and established entrepreneurs in the different phases of the entrepreneurial journey. Through a quantitative survey of university students in tourism and hospitality, the study analyses how gender relates to latent and nascent sustainable entrepreneurship. A qualitative approach is further taken to the study of established entrepreneurs both because it allows exploration of the gendered 
complexity of sustainability, and because of the difficulties in identifying a sufficiently large sample for a quantitative analysis of this group. This design has a complementarity purpose, as the interviews supplement the survey, providing further nuance and complexity in understanding sustainability (Xiao, 1997, p. 364; Truong, Liu \& Yu, 2020).

This analysis follows the entrepreneurial journey, through different samples and methods that adapt to the research methodological limitations in each stage. There are limitations since this involves two contrasting cross-sectoral, rather than a longitudinal, analysis, but it is still - to the best of our knowledge - the first study of different stages of the journey to sustainable entrepreneurship.

\subsection{Study A. Quantitative analysis - Survey}

Research question and hypothesis: Following on from the broad aims set out in the introduction, the quantitative analysis addresses four main research questions, with related hypotheses, that will be approached through a gendered lens:

- Research question 1: Are women more interested than men in sustainability issues around entrepreneurship?

- H1. Women are more interested in sustainability in entrepreneurship in tourism (Ngoasong \& Kimbu, 2019; Kimbu \& Ngoasong, 2016; Marlow, 1997; Outsios \& Farooqi 2017; Moreno-Alarcón \& Cole, 2019; Roomi et al. 2009)

- Research Question 2: How does PAE influence the importance attached to sustainability?

- H2. Perceived attitude towards entrepreneurship (the capacity to identify business opportunities and become an entrepreneur) impacts positively on the importance attached to sustainability in entrepreneurship (Cohen \& Winn, 2007; Dean \& McMullen, 2007; Crnogaj et al. 2014; Koellinger et al. 2013; Hallak et al. 2013).

- Research Question 3: What is the influence of BC on the importance attached to sustainability?

- H3a. Higher BC impacts positively on the importance attached to sustainability in entrepreneurship (Bamberg \& Möser, 2007; Ngoasong \& Kimbu 2016; 2019

- H3b, Higher BC has a positive impact on having a PA (; Ajzen, 2002;De Groot \& Steg, 2009).

- Research Question 4: How does risk acceptance influence the importance attached to sustainability and attitudes towards entrepreneurship?

- H4a. The higher the risk acceptance the greater the importance attached to Sustainability in Entrepreneurship (seen as an opportunity) (Dean \& McMullen, 2007; Ateljevic \& Doorne, 2000).

- H4b. Higher risk acceptance has a positive impact on a positive personal perception of BC (Barbosa et al. 2007; Keh, Der Foo \& Lim 2002). 
- H4c. Higher risk acceptance has a positive impact on a positive personal perception of PAE (Williams et al. 2020, Williams \& Baláž 2015, Hall \& Williams, 2019; Zhang et al., 2020).

Research instrument. Data were collected using a structured questionnaire to understand tourism and hospitality university student's perception of entrepreneurship as a career path in Spain. A pilot study was conducted (50 respondents) leading to minor revisions of the research instrument (Dayour et al. 2019). The survey was based on previously tested scales about PAE, perceived support and barriers, entrepreneurial knowledge, perceived $\mathrm{BC}$, networking, the relevance of sustainability and risk management, as well as socio-demographic characteristics (see Annex 1). All items are measured using the same 5-point Likert scale, requesting a level of agreement (Strongly agree, Agree, Neither agree nor disagree, Disagree, Strongly disagree) with each item.

Data collection and procedure. The focus on students is supported by (1) the strong relationship between education and entrepreneurship (Santero-Sanchez et al. 2015); (2) the high percentage of the population aged 18-30 studying at university in Spain (2015, UNESCO Gross Enrolment Ratio (GER) of $86.67 \%$ ); and (3) access and convenience sampling needs.

The population are undergraduate students in tourism studies in Spain, where there were 26,735 students in tourism in 2016 (Source: S.G. de Coordinación y Seguimiento Universitario. Ministerio de Educación, Cultura y Deporte), implying a minimum sample size of 359 participants. Data collection started in January 2019 and finished in September 2019. 892 completed questionnaires were received from 14 universities drawn from the range of the autonomous regions (Madrid, Andalusia, Catalonia, Canary Islands, Galicia, Cantabria). After removing all incomplete questionnaires, a total of 562 was included in the analysis. As the current study only focuses on students that are already entrepreneurs, already taking steps to become entrepreneurs or potentially interested in becoming entrepreneurs, the 23 respondents not interested in entrepreneurship $(4,1 \%)$ were excluded. The final sample had 539 respondents, of which $70.3 \%$ were women and $29.7 \%$ were men, reflecting the over representation of women in this academic area (Pritchard \& Morgan, 2017; Chambers et al. 2017). All the participants were residents in Spain: while $78.7 \%$ were Spanish, 9.8\% were European (not including Spain), and $5.9 \%$ from Central and South America.

Data analysis: Descriptive analysis and Structural Equation Models (SEM), with AMOS 26, were performed.

\subsection{Study B. Qualitative analysis - interviews}

Research instrument: Interview design. The semi-structured interviews were based on a general script, but the interviewee had enough flexibility to develop their own speech. The script was based on Risman's (1998) theory "Gender as a Social Structure", and the adaptation of Segovia-Perez et al (2019) to the hospitality industry. The interviews sought to explore the gendered aspects of the entrepreneurial journey, and how this was negotiated by individuals, at an individual, interactional and institutional level. Sustainability being a dominant theme in the ways participants narrated and made sense of such entrepreneurial journeys. All the interviews started with the question about how they had 
become entrepreneurs. This general and open question lead to more specific questions around the previously mentioned theory, when needed.

Data collection and procedure. Sample. Women's entrepreneurship in tourism has been highly selective, typically being linked to stereotypical women's home and family care work (Peeters \& Ateljevic, 2009); e.g. handicrafts (Kwaramba et al. 2012), the Sharing Economy (Juul, 2015), and social entrepreneurship (Kimbu \& Ngoasong, 2016). Therefore, in order to avoid stereotyping, the sample sought to incorporate male and female entrepreneurs who have the tools and the skills to challenge the roles they have been traditionally assigned in the industry (Costa et al. 2013). Although snowball sampling was used, multiple entry points drew on the range of experiences in the different tourism subsectors: Hospitality (accommodation and restaurant industry); commercialization (communication and distribution); transportation; events or other tourist services; and high-tech organizations. We also considered geographic location (rural-urban differential), when selecting entrepreneurs. In total, 19 interviews were undertaken. A complete description of the participants is included in Annex 2.

Data Analysis. N-VIVO 12 was used to support a post structuralist thematic analysis (deconstruction) to identify interconnections and explanations associated with specific social-economic contexts. Two researchers undertook and evaluated an analysis of the interview transcripts in two-phases (SegoviaPerez et al. 2019; Hsieh and Shannon, 2005). The initial inductive process (phase 1) identified a long list of issues around tourism entrepreneurship, regardless of gender: motivations, encountered barriers, critical success factors, risk, training, funding and the importance of networking. The inductive process was followed by a deductive process (phase 2) that raised the issues identified as relevant for sustainability support through SEM. These main issues were PAE, CB and risk management. These issues were evaluated from a gender perspective, differentiating interventions from men and women. This analysis allowed the identification of similarities and differences towards the relevance of entrepreneurship and the gendered impact of PAE, BC and risk on the relevance of sustainability.

\section{FINDINGS}

\subsection{Study A. Quantitative analysis - Survey}

Entrepreneurship is a potential career path for most participating students with only $4.1 \%$ of the respondents rejecting this possibility. These results are aligned with other studies of university students (e.g. del Rio et al. 2016), which indicate that higher levels of education have a positive impact on entrepreneurial intention (GEM, 2001-2019).

In the current study, although the numbers are small, women seem a little more negatively biased towards entrepreneurship (4.5\% never want to become entrepreneurs, compared to men, $3 \%$ ). These results were expected since the literature indicates that women have lower entrepreneurial intentions than men (Wilson et al. 2007; Nowiński et al. 2019).

In relation to Research Question 1, the evaluation throughout the entrepreneurship path shows how a very similar percentage of women and men are already entrepreneurs (6.33\% and $6.24 \%$ respectively), though more men are more likely than women to be taking steps towards entrepreneurship (nascent entrepreneurship) (9.38\% and 3.96\%, respectively). Regarding latent entrepreneurship, men and 
women are broadly similar: respectively, $26.88 \%$ and $26.65 \%$ want to become entrepreneurs in less than three years, and $63 \%$ and $57.5 \%$ want to do so eventually. In comparison, in 2018 , only $17 \%$ of men in the European Union (28 countries) and $9 \%$ of women were entrepreneurs; it is highly likely that many of the latent entrepreneurs will not complete the entrepreneurial journey.

The general literature (e.g. Kimbu \& Ngoasong, 2016; De Silva \& Pownall, 2014; Glass et al. 2015) shows how women students tend to give more support to sustainable ideas about entrepreneurship. In relation to the relevance of sustainability among latent and nascent entrepreneurs among university students, the majority of participants in the study agree or strongly agree that firms should take a leading role in the field of sustainability (S4) (89.05\%; mean $=4.4$ for women and 4.7 for men), and that firms that care and are environmentally and socially sustainable have advantages in recruiting and retaining qualified employees (S5) (74.21\%; mean= 3.97 for women and 3.98 for men). A gender perspective informs that women were more likely to state that the environmental performance of a company will be considered more important by financial institutions in future (S3) $(78.85 \%$; mean $=4.15$ for women and 3.97 for men), that Corporate Social Responsibility (CSR) should be foundational for companies (S2) (83.67\%; mean $=4 . .30$ for women and 4.09 for men) and that environmental problems are one of the biggest challenges for society (S1) (88.13\%; mean= 4.49 for women and 4.36 for men). Results show how women are positively biased towards more than half of the variables explaining the importance given to sustainability (S3, S2 and S1) with S3 and S2 being statistically significant (Pearson ChiSquare=9.201; $p=0.5)$, but do not have significantly higher interest in all aspects of sustainability. Sustainability in entrepreneurship is important for men and women, in different ways.

This dichotomous position towards sustainability - either you are or are not interested in sustainability as an entrepreneur - from a gender perspective is in practice blurred, as suggested by post-structuralist perspectives, as will become evident when considering the findings of the Structural Equation Modelling (SEM).

To support the previous statistical analysis and to understand the construction of sustainable entrepreneurship in university students, and how this is influenced by gender and other gendered variables related to sustainability and entrepreneurship, Structural Equation Modelling (SEM) was performed. The conceptual model was validated using CFA (Joo et al. 2019; Dayour et al. 2019) and a two-step approach was adopted. A validation of the conceptual model using CFA was followed to ensure the fit of the data in the model as well as test the hypotheses. (See Appendix 3 for detailed analysis)

The final set of variables Table A1 in Annex 3) included in the model are the following, and the Squared Multiple Correlation shows how the independent variables (Gender, BC, PAE, Risk) explain $17 \%$ of the dependent variable (Sustainability).

SUSTAINABILITY: S1 (Environmental problems are one of the biggest challenges for our society); S2 (Corporate social responsibility should be part of the foundations of each company); S3 (The environmental performance of a company will be considered more and 
more by financial institutions, in the future); S4 (Firms should take a leading role in the field of sustainability).

RISK: R1 (I adapt more flexibly to new situations than my friends); R2 (I manage my problems better than my friends); R3 (I would adapt better to changing living conditions than my friends); R4 (I am willing to take more risks than my friends).

PERCEIVED ATTIT. TOWARDS ENTREPRENEURSHIP (PAE): P1 (If I had the opportunity and resources, l'd like to start a firm); P2 (Being an entrepreneur would entail great satisfaction for me); P3 (Among various options, I would rather be an entrepreneur).

PERCEIVED BEHAVIOURAL CONTROL (BC): B1 (Creating and putting into operation a new venture); B2 (Interacting with key people to raise capital to create a new venture); B3 (Recognizing opportunities in the market for new products and/or services); B4 (Negotiating and maintaining favorable relationships with potential investors and banks); B5 (Keeping the new-venture creation process under control); B6 (Defining your business idea and a new business strategy).

The SEM model confirms that the interest in sustainability within entrepreneurship was jointly predicted by Gender as a moderator, and specifically by being a woman $(\beta=0.177 ; p<0.000)(H 1$ is confirmed) Further to this, the SEM confirms that PAE has a direct and positive relationship $(\beta=0.153 ; p<0.000)$ ( $\mathrm{H} 2$ is confirmed) with sustainable entrepreneurial relevance (see Table A3, Annex 3 ). This construct relates to the satisfaction entailed within entrepreneurship and what it means, as well as an entrepreneur's orientation to innovation, society and the environment (Cohen \& Winn, 2007; Dean \& McMullen, 2007; Crnogaj et al. 2014).

The study sought to explore relations between $B C$ and the importance given to Sustainable Entrepreneurship. The SEM results confirm $B C$ has a positive impact on sustainability $(\beta=0.108$; $p<0.006)$ ( $H 3 a$ is confirmed) and entrepreneurs' PAE $(\beta=0.233 ; p<0.000)(H 3 b$ is confirmed) and (see Table A3, Annex 3). BC, in this context refers to a wide range of variables that are relevant for innovation and entrepreneurship (Kraft et al. 2005; Ajzen, 2002; Ngoasong \& Kimbu 2016; 2019): including, for example, creating and putting into operation a new venture; interacting and negotiating with people; recognizing new opportunities; and keeping new projects under control.

Finally, the SEM results confirm the relevance of Risk for Sustainable Entrepreneurship. Risk, a highly gendered variable, has a positive impact on the importance attached to sustainability $(\beta=0.158$;

$p<0.000)$ ( $\mathrm{H} 4 \mathrm{a}$ is confirmed), student's perception of their $B C(\beta=0.519 ; p<0.000)(\mathrm{H} 4 \mathrm{~b}$ is confirmed), and PAE ( $\beta=0.188 ; p<0.005)$ ( $H 4 c$ is confirmed) (see Table $A 3$, Annex 3$)$. These results are aligned with extant research on the capacity to innovate and take risks in entrepreneurship (e.g. Williams et al. 2020, Williams \& Baláž, 2015, Hall \& Williams, 2020). The findings also support Dean \& McMullen's (2007) insights regarding how sustainability in entrepreneurship can be seen as a market failure and/or render uncertain environments.

\subsection{Study B. Qualitative analysis - interviews}


While the quantitative and qualitative analyses are not directly comparable, in this section we seek to provide further nuanced insights into the gendered nature of sustainable entrepreneurship by considering the views and experiences of established entrepreneurs.

The qualitative findings presented thus far align with the SEM Hypothesis testing, which sought to examine the relations between variables - with women being identified as being more engaged and motivated by sustainability.

In the entrepreneur's interviews, gender was important in understanding the intersection of sustainability and entrepreneurial performance (Research Question 1). The deductive process indicates that whilst both women and men are interested in sustainability, for women sustainability has a more pivotal role. For example, all women participants integrated environmental and/or social sustainability into the design of their products and services:

We have created a company with three objectives...to improve the health of people in the city, save the planet and fix rural population (WomEnt_02, woman)

We want to bring mindfulness to our surroundings and to tourists. We want to help. (WomENt_8, woman)

Sustainability was also understood as a motivating reason for many women to become entrepreneurs:

It arose from a family need, basically, when my daughters were born because I am very worried about food, and well, also in what is a little healthy, where to buy organic products, that were not at disproportionate prices, and above all not only ecological but also had a certain guarantee of origin. (WomENt_04, woman)

We really like the bio-construction [of the hotel], here are materials that...for example, we made, and that was important for us. (WomENt_06, woman)

Importantly, sustainability narratives were less evident within the men's accounts. When they did emerge, they tended to be framed within the context of broader structural frameworks (such as the Sustainable Development Goals (SDGs)) and how their business might benefit from alignment with such frameworks. As evident in MenENt_06's narrative:

These are opportunities that you detect there, right? So, when you see that works at the political level and that anything that carries the SDGs ahead seems like it is already done, the project is already half done, so then, we jump on the bandwagon. (MenENt_06, man)

Social sustainability, moreover, was identified as particularly important for the women entrepreneurs, with several participants being engaged in social development across varying local, national and international scales:

We buy everything we can from local producers. It is important to help our neighbors. (WomENt_05, woman)

These are opportunities that you are detecting to give visibility to female entrepreneurship, ... if I think I can make a small change, I will. I have to make female entrepreneurship visible so 
that things are not just about finishing your career and looking for a job. There are more options. (WomENt_09, woman)

Again, the value in supporting social sustainability was also visible in MenENt_02's (man) account: The town where it is located, and its people are important to us. Yet, it was notable that within the narratives of the male participants, less time and focus was granted to the role of enterprises within specific social contexts. MenENt_02's account services to represent the more abstract and brief engagement given to concerns about social sustainability, within the context of male entrepreneurial journeys.

A particular area of social concern for women participants was human resource management, with team engagement being key to women's entrepreneurial performance:

I prioritize a model of self-management where people find their fulfilment by doing the project that... what else... in which they feel most, in which they see the most. I think it's going to be a winning concept because people are going to be happy and going to give their best. (WomEnt_02, woman)

For me it is very important that my colleagues also find that point of personal development within the company. (WomENt_03, woman)

In the end I am looking for a long-term collaboration. If the person is good, I want them to retire with me... The most important thing for me is the commitment of that person and to establish a link with them. (WomENt_09, woman)

Whilst again being less evident across the interviews, men also highlighted the importance of social responsibility in entrepreneurial management:

For me the team is fundamental. I want them to talk, to feel part of this. Your personal development is fundamental to me. (MenENt_07, man)

When evaluating interviews with entrepreneurs in the consolidated and growth phases, the main differences arise around the motivation behind their entrepreneurial ventures and the varying starting points for the entrepreneurial journeys. Their starting point and their PAE are quite diversified (Research Question 2). WomENt_02, MenENt_05, WomENt_09 and MenENt_01, for example, all had a persistent feeling about doing something different, and they had long felt they would become entrepreneurs. Others, like WomENt_01, MenENt_06, MenENt_07, WomENt_03 and WomENt_05 became entrepreneurs as a result of their professional experience as employees; they needed more, and entrepreneurship fulfilled those needs. MenENt_04, WomENt_07, MenENt_03 and WomENt_08 turned to entrepreneurship out of necessity, while others, such as WomENt_04 and MenENt_02, identified market opportunities. The diverse map of motivations that leads these entrepreneurs towards their journey does not appear to be perceived and narrated through a gendered lens and the interviews can't identity any relationship between PAE and the importance given to sustainability.

The finding within the literature that women are more risk averse than men (e.g. De la Fuente-Cabrero et al. 2014; Brush et al. 2009) was also evident in our qualitative interviews with entrepreneurs. However, the qualitative narratives also provide more insights into the nuanced relations between 
women and risk; whereby women were found to accept risk, as long as it is managed conservatively (Research Question 4):

I believe that [entrepreneurship] is a risk, and from my point of view we have always been much more realistic and cautious in how to do things, how to spend money. In entrepreneurship it is important to start with the minimum risk. (WomENt_03, woman)

I have always clung to the false stability of a fixed job, every month I get my salary, not much, but I have my salary. (WomENt_08, woman)

Others held much more complex notions of risk, highlighting the fluidity of risk perception and the limitations in attempting to uphold fixed notions of women as necessarily and innately risk averse:

I give importance to risk. However, in the end that focus is not usually required. (WomENt_09, woman)

Whilst a further set of women entrepreneurs exhibited more masculine discourses in their narration of risk; these serve to question constructions of women as risk averse and contest gendered assumptions within the literature:

I am not worried about uncertainty, that is, I am not afraid, I am not paralyzed. (WomENt_02, woman)

To become an entrepreneur was a very deep reflection that I made personally when I decided that we had to look for a Plan B. Yet, the reality is that we were quite unconscious. I want to say that I believe that much of what we do as entrepreneurs is done by illusion. (WomENt_05, woman)

Men, by contrast, conformed to gendered expectations found within the literature, which suggest they are less concerned with risk. The interview narratives indicate that men's positive perception regarding behavioural control (particularly within the context of enterprise objectives and outcomes), assisted in heightening confidence and reducing perceptions of risk:

To control the risk, I control the objectives, I can control the way we work, I can bring the team I work with, and then that risk exists, of course, I will define it, I will go every time dwarfing more. (MenENt_05, man)

I am quite unconscious in the sense that I am quite thrown and, and no, and I don't stop to think about the consequences, but I do it with knowledge of the cause. (MenENt_03, man)

Fear is a sensation that I believe that any entrepreneur has, but that you have to know how to tame it, you have to know how to placate it. How? I believe that, basically, with a blind confidence in yourself and in your project. (MenENt_02, man)

Despite possessing high confidence in relation to behavioural control and risk, many men entrepreneurs were involved in large scale, tech organizations; enterprises that are, arguably understood as highly vulnerable to failure and external influence (Reid \& Smith, 2002). Such disconnections between context 
and risk perception highlight the influence of gender in making sense of risk and behavioural control within entrepreneurial performance.

It is not possible to identify how BC impacts sustainability, within the context of the interviews. It is possible, however, to explore relations between BC and gender (Research Question 3). The women's entrepreneurship narratives appeared to conform to gendered expectations (Braun, 2010; Ngoasong \& Kimbu, 2019), that suggest women are less likely to exhibit high levels of behavioural control:

Women still question whether we have to talk, because much more has always been questioned. (WomENt_03, woman)

Although we don't know, we have a lot of capacity, we are prepared, we have been gifted to raise children, to give birth. I believe that we have many super powers that men do not have, so we should use them ... Just like we manage our house and we are very good managers.

(WomENt_08, woman)

Crucially, there is a complex positioning of $\mathrm{BC}$ within these qualitative narratives. On one level, the women participants were clear and open in their hesitancies and vulnerabilities within the entrepreneurial context - suggesting low levels of BC. And yet, at the same time, we can see that low levels of $\mathrm{BC}$ are not necessarily the perceptions of the women themselves but rather stem from broader social constructions that position women's abilities. WomENt_08, for example, is quick to question these constructions in stating her belief in the 'super powers' of women, whilst WomENt_03 confirms that it is the questioning from others that influences perceptions.

Nevertheless, such perceptions influenced the ways women participants tended to position themselves within the enterprise, taking on high levels of planning and low-profile positions:

Well, I like to be the one that is often not seen, but it is the one that helps behind the team. (WomENt_09, woman)

Planning is perhaps more my strength. (WomENt_05, woman)

Such positionings contrast to those within the narratives of some of the men entrepreneurs:

I am a nonconformist, I do not usually like anything of 'no' for an answer, I ask why not, or why. (MenENt_05, man)

Men too were transparent in sharing concerns with planning and learning, undertaken throughout the entrepreneurial journey - likewise, deconstructing masculine expectations concerning high levels of confident and controlling performance:

I have learned.... Well, look, assuming I have no fucking idea of anything, because that's the way it is, really. Really. Reading a lot, finding out about things I did not know, by people who could give me their experience, and especially surrounding me with people who knew things that I do not know. (MenENt_05, man)

Success? Always surround myself with people who know more than me, and in the end that feedback makes you, if you are a bit shabby. (MenENt_03, man) 


\section{CONCLUSIONS}

This article provides three main contributions to the literature on sustainable tourism entrepreneurship. First, in utilising a mixed-methods post-structuralist approach, we uncover some of the circumstances under which men and women engage in sustainability at different points in the entrepreneurial journey, as well as the importance they attach to sustainability in tourism entrepreneurship. The women in this study tended to give considerable importance to specific aspects of sustainability, particularly the social and environmental dimensions, when engaging with tourism entrepreneurship (cf Kimbu \& Ngoasong, 2016; De Silva \& Pownall, 2014); confirming previous studies (Walls et al. 2012; Glass et al. 2015). Building on these ideas, we found that when men were concerned with sustainability, it tended to be conceptualized within the context of potential economic contributions if they focused on the environment and social dimensions of sustainability.

The research also unpacks some of the complexity in this picture by following up our principal focus on latent and nascent entrepreneurs with a further analysis of interviews with a group of established entrepreneurs. Although for university students, mostly at the latent and nascent stages of entrepreneurship, gender has an impact, this does not follow simple dichotomous lines. Women students are more likely to attach importance to the social and environmental aspects of sustainability, and the risk variable (conceptually, known to be highly gendered) is also significant, but neither behavioural control or personal attitudes seem to be gendered at this stage of the journey. Amongst more established entrepreneurs, men and women, engage in sustainability differently, and in different areas. Sustainability is an important motivator for women entrepreneurs, strongly linked to the potentials of their entrepreneurship to generate environmental products and inclusive workplace environments, while men are more likely to see sustainability in terms of business opportunities. There are gender differences in approaches to risk, although these are complex, with women commenting on both their concerns, and social constructions of gender differences, while there are considerable variations in the extent to which men express their competence, or perhaps over-confidence, to manage risks and uncertainty. Gender differences are more blurred in terms of behavioural control, and absent in respect of personal attitudes. Therefore, as the findings from our analyses of individuals at different stages of the journey to entrepreneurship indicate, in keeping with post-structuralist perspectives gender differences should not be essentialised.

Second, our research approach contributes to developing a theoretical framework for unpacking and resolving tensions in understanding relations between gender and behaviour in sustainable tourism entrepreneurship. This study highlighted that, even though BC has a positive impact on the entrepreneurs' PAE and on sustainability, societal attitudes which construct, and stereotype women's abilities and capabilities directly influence their propensity to take risk and introduce specific innovations (Williams et al. 2020; Kraft et al. 2005; Ajzen, 2002). Societal attitudes constrain the actions of women participants, meaning they are less likely to engage in 'risky behaviours', negatively influencing their likely engagement with sustainable (tourism) entrepreneurship. By contrast, men entrepreneurs are traditionally seen as being confident risk takers. However, unlike previous studies (cf. De la FuenteCabrero et al. 2014; Brush et al. 2009) which indicate women are risk averse (in all circumstances), our 
findings caution against such generalisation; there were multiple perceptions and performances relating to risk, with some women being tolerant of risk if it could be carefully managed. We suggest that such an awareness, yet tolerance, of risk may be an influential positioning for tourism entrepreneurs of all genders who are seeking to engage with sustainability, but that uncertainty (unknown risk) may be a key discriminator (Williams et al, 2020) which requires further investigation.

Extending these ideas, our third major contribution is revealing the complexity of engaging in sustainable entrepreneurship (in tourism) in which societal perceptions and PAE inhibit women's risktaking propensities (Marlow \& Swail, 2014; Zhang et al., 2020) but encourages pro-environmental and prosocial behaviours. This results in women not accessing and acting on resources and opportunities in a timely manner, constraining them to focus more on social and environmental dimensions of sustainability to the detriment of the economic dimension; thereby impacting on their business performance. Women tourism entrepreneurs, just like men, need to be capacitated to become more independent, confident and able to access resources (Outsios \& Farooqi, 2017) that enable them to undertake business activities in ways that consider all three dimensions of sustainability. By examining the different enabling variables (PAE, $B C$, risk), we have demonstrated the initial conditions, triggering events and self-reinforcing mechanisms (Bidegain Ponte, 2017; Moreno-Alarcon, \& Cole, 2019; Kraft et al. 2005) needed to start-up and ensure engagement in entrepreneurship by women (and men) and the effects of these on their engagement in sustainability and the sustainability of their businesses.

Our findings have policy implications for fostering gender equality through sustainable entrepreneurship in tourism, including questioning how women tourism entrepreneurs are often associated with traditional caring roles when enacting sustainable entrepreneurship (Figueroa-Domecq et al. 2020) rather than being constructed as valuable, conscious and responsible business choices. Extant tourism policies are also gender neutral and primarily focused on economic sustainability, rendering limited engagement with social and environmental sustainability. This particularly impacts women tourism entrepreneurs who, as we have identified, are more likely to engage in social and environmental sustainability, whilst attaching less significance to economic sustainability compared to men (UNWTO, 2019). Creating enabling environments and opportunities through policy initiatives at the macro and micro levels that specifically recognise gendered distinctions should be prioritised. Public sector bodies can encourage entrepreneurs concerned with environmental and social sustainability by providing training and enabling market access. As Ngoasong and Kimbu (2019, p.55) note, "these interventions can enable women entrepreneurs to move beyond their own entrepreneurial goals to secure buy-in from those who are otherwise resistant or indifferent" to engaging in all three dimensions of sustainability in tourism entrepreneurship. Otherwise, women's sustainable entrepreneurial performances will continue to be undervalued; a construction that may inhibit the capacity for sustainable tourism entrepreneurship to be utilised to help achieve the SDG's and, crucially and paradoxically, counter the SDG of 'gender equality'.

Finally, it is important to re-emphasise that as this study drew on findings from two populations, using different methodologies, they are not directly comparable. Therefore, it would be beneficial, in future studies, to undertake longitudinal research to gain further insights into how individual entrepreneurs' perceptions and approaches to sustainability shift across the entrepreneurial journey. We further 
suggest that, as revealed within this study, mixed methods approaches are beneficial in rendering both broad scale and nuanced insights into how gender influences sustainability and tourism entrepreneurship. Moreover, a deeper understanding of the intersections of gender and sustainability within the context of tourism entrepreneurship is required, if the medium of entrepreneurship is to be used to achieve the SDGs. For this reason, extending this research beyond the Spanish context will render more complex insights into the multiple ways through which gender influences sustainability perceptions and approaches through tourism entrepreneurship. Further, in recognising the dominance of research on tourism entrepreneurship in the Global North, we argue that future investigation should focus on how sustainability is influenced by gender in Global South contexts.

\section{Notes}

1. As a result, one item from PAE was removed (P4 Being an entrepreneur implies more advantages than disadvantages), one from BC (B7. Having a successful business), and one from (S5) Firms that care and are sustainable from environment and social perspectives, have advantages in recruiting and retaining qualified employees).

2. Model fit was assessed using the criteria proposed by Hu and Bentler (1999 (in Landon et a. 2018): Root Mean Square Error of Approximation (RMSE) $<=0.07$; Comparative Fit Index $(\mathrm{CFI})<=0.95$; Nonnormed Fit Index $(\mathrm{NNFI})<=0.95$.

3. Convergent validity, or the extent to which a set of measures reflect the theoretical latent construct, those items are designed to measure (Hair et al. 2010 in Landon et al., 2018), was considered acceptable if standardized factor loadings were significant above 0.5 (Dayour et al., 2019). Discriminant validity was said to be achieved if the squared correlation between two latent constructs did not exceed the AVE for either.

\section{Notes on contributors}

Dr. Cristina Figueroa Domecq . School of Hospitality and Tourism Management, University of Surrey, Stag Hill, University Campus, Guildford GU2 7XH, United Kingdom. Email: c.figueroadomecq@surrey.ac.uk. Marie Curie Research Fellow in the School of Hospitality and Tourism Management, University of Surrey (UK). Her research focusses on gender studies in tourism, especially entrepreneurship and management.

Dr. Albert N. Kimbu . School of Hospitality and Tourism Management, University of Surrey, Guildford GU2 7XH, United Kingdom \& School of Tourism and Hospitality, University of Johannesburg, Johannesburg, South Africa Email: a.kimbu@surrey.ac.uk. Senior Lecturer in the School of Hospitality and Tourism Management, University of Surrey (UK) and Senior Research Associate in the School of 
Tourism \& Hospitality, University of Johannesburg (South Africa). He researches stakeholder networks, trust, gender and entrepreneurship in hospitality and tourism.

Dr. Anna de Jong . School of Interdisciplinary Studies, University of Glasgow, Rutherford/McCowan Building, Crichton University Campus, Dumfries DG1 4ZL, Scotland. Email: anna.deJong@glasgow.ac.uk. Her research is concerned with inequality in tourism and event planning and development.

Prof. Allan. M. Williams . School of Hospitality and Tourism Management, University of Surrey, Stag Hill, University Campus, Guildford GU2 7XH, United Kingdom. Email: allan.williams@surrey.ac.uk. Professor of Tourism and Mobility Studies in the School of Hospitality and Tourism Management, University of Surrey (UK). He researches innovation, knowledge, migration and entrepreneurship in tourism. He is a former co-editor of Tourism Geographies and European Urban and Regional Studies, and a fellow of the Academy of Social Science.

\section{REFERENCES}

Ahl, H. \& Marlow, S. (2012). Exploring the dynamics of gender, feminism and entrepreneurship: advancing debate to escape a dead end? Organization, 19(5), 543-562.

Ahl, H. (2006). Why research on women entrepreneurs needs new directions. Entrepreneurship: Theory \& Practice, 30(5), 595-621;

Ahl, H., \& Marlow, S. (2019). Exploring the false promise of entrepreneurship through a postfeminist critique of the enterprise policy discourse in Sweden and the UK. Human Relations, 1-28.

Ajzen, I. (1991). The theory of planned behavior. Organizational Behavior and Human Decision Processes, 50(2), 179-211.

Ajzen, I. (2002). Perceived behavioral control, self-efficacy, locus of control, and the theory of planned behavior 1. Journal of Applied. Social Psychology, 32, 665-683.

Ateljevic, I., \& Doorne, S. (2000). 'Staying within the fence': Lifestyle entrepreneurship in tourism. Journal of Sustainable Tourism, 8(5), 378-392.

Bamberg, S. \& Möser, G. (2007). Twenty years after Hines, Hungerford, and Tomera: A new metaanalysis of psycho-social determinants of pro-environmental behaviour. Journal of Environmental Psychology, 27, 14-25.

Barber, B.M., \& Odean, T. (2001). Boys will be boys: Gender, overconfidence, and common stock investment. The Quarterly Journal of Economics 116(1), 261-292. 
Barbosa, S. D., Gerhardt, M. W., \& Kickul, J. R. (2007). The role of cognitive style and risk preference on entrepreneurial self-efficacy and entrepreneurial intentions. Journal of Leadership \& Organizational Studies, 13(4), 86-104.

Barrett, M. (1995). Feminist perspectives on learning for entrepreneurship: the view from small business. In Bygrave, W.D., Bird, B.J., Birley, S., Churchill, NC, Hay, M., Keeley, R.H. and Wetzel, W.E., Jr (Eds), Frontiers of Entrepreneurial Research, Babson College, Boston, MA, 323-336.

Betz, M., O'Connell, L. \& Shepard, J.M. (1989). Gender differences in proclivity for unethical behavior. Journal of Business Ethics 8(5), 321-324.

Bidegain Ponte, N. (2017). La Agenda 2030 y la Agenda Regional de Género: sinergias para la igualdad en América Latina $y$ el Caribe. Santiago: United Nations. Available online: https://repositorio.cepal.org/bitstream/handle/11362/41016/S1700105A es.pdf?sequence $=7$

Boley, B.B., McGehee, N.G., Perdue, R.R., \& Long, P. (2014). Empowerment and resident attitudes toward tourism: Strengthening the theoretical foundation through a Weberian lens. Annals of Tourism Research, 49, 33-50.

Bönte, W., \& Piegeler, M. (2013). Gender gap in latent and nascent entrepreneurship: driven by competitiveness. Small Business Economics, 41(4), 961-987.

Braun, P. (2010). Going green: women entrepreneurs and the environment, International Journal of Gender and Entrepreneurship, 2(3), 245-259.

Brush, C. G., De Bruin, A., \& Welter, F. (2009). A gender-aware framework for women's entrepreneurship. International Journal of Gender and Entrepreneurship, 1(1), 8-24.

Camelo-Ordaz, C., Diánez-González, J.P. \& Ruiz-Navarro, J. (2016). The influence of gender on entrepreneurial intention: The mediating role of perceptual factors. BRQ Business Research Quarterly, 19(4), 261-277.

Carlsson-Kanyama, A., Julia, I., \& Röhr, U. (2010). Unequal representation of women and men in energy company boards and management groups: Are there implications for mitigation? Energy Policy, $38,4737-4740$.

Chambers, D., Munar, A.M., Khoo-Lattimore, C., \& Biran, A. (2017). Interrogating gender and the tourism academy through epistemological lens. Anatolia, 28(4), 501-513.

Chung, J.T. (1998). Risk reduction in public accounting firms: are women more effective? International Review of Women and Leadership, 4(1), 39-45.

Cohen, B., \& Winn, M.I. (2007). Market imperfections, opportunity and sustainable entrepreneurship. Journal of business venturing, 22(1), 29-49. 
Costa, C., Carvalho, I., Caçador, S., \& Breda, Z. (2013). Gender and entrepreneurship in tourism: An analysis of tourism graduates' entrepreneurial profile. Revista Turismo \& Desenvolvimento, 2(17/18), 623-635.

Crnogaj K., Rebernik, M., Hojnik, B.B., \& Gomezelj, D.O. (2014). Building a model of researching the sustainable entrepreneurship in the tourism sector. Kybernetes, 43, 377-393.

Dahles, H., Khieng, S., Verver, M., \& Manders, I. (2020). Social entrepreneurship and tourism in Cambodia: advancing community engagement. Journal of Sustainable Tourism, 28(6), 816-833.

Dayour, F., Park, S., \& Kimbu, A. N. (2019). Backpackers' perceived risks towards smartphone usage and risk reduction strategies: A mixed methods study. Tourism Management, 72, 52-68.

Dean, T. J., \& McMullen, J. S. (2007). Toward a theory of sustainable entrepreneurship: Reducing environmental degradation through entrepreneurial action. Journal of Business Venturing, 22(1), 5076.

De Groot, J.I. \& Steg, L. (2009). Morality and prosocial behavior: The role of awareness, responsibility, and norms in the norm activation model. Journal of Social. Psychology, 149, 425-449.

De la Fuente Cabrero, C., Segovia-Perez, M. \& Figueroa-Domecq, C. (2014). Implications of financial institution support for women's business projects. ESIC Market Economic and Business Journal, 45(3), 515-552.

De Silva, D.G. \& Pownall, R.A.J. (2014). Going green: does it depend on education, gender or income?, Applied Economics, 46(5), 573-586.

Dean, T.J. \& McMullen, J.S. (2007). Toward a theory of sustainable entrepreneurship: Reducing environmental degradation through entrepreneurial action. Journal of Business Venturing, 22(1), 5076.

del Rio, M.D.L.C., Peris-Ortiz, M., Álvarez-García, J., \& Rueda-Armengot, C. (2016). Entrepreneurial intentions and entrepreneurship education to University students in Portugal. Technology, Innovation and Education, 2(1), 7.

Duffy, L.N., Kline, C.S., Mowatt, R.A., \& Chancellor, H.C. (2015). Women in tourism: Shifting gender ideology in the DR. Annals of Tourism Research, 52, 72-86.

Figueroa-Domecq, C., Palomo, J., Flecha-Barrio, M.D., \& Segovia-Pérez, M. (2020). Technology double gender gap in tourism business leadership. Information Technology \& Tourism, 1-32.

Figueroa-Domecq, C., de Jong, A., \& Williams, A. M. (2020). Gender, tourism \& entrepreneurship: A critical review. Annals of Tourism Research, 84, 102980. 
Filieri, R., Alguezaui, S. \& Mcleay, F. (2015). Why do travelers trust TripAdvisor? Antecedents of trust towards consumer-generated media and its influence on recommendation adoption and word of mouth. Tourism Management, 51, 174-185.

Glass, C., Cook, A., \& Ingersoll, A.R. (2015). Do Women Leaders Promote Sustainability? Analyzing the Effect of Corporate Governance Composition on Environmental Performance. Business Strategy and the Environment, 25(7), 495-511.

Global Entrepreneurship Monitor (GEM) (2019). Global Report 2018/2019. Available online: https://www.gemconsortium.org/report/gem-2018-2019-global-report

Global Volunteers (2019). The Global Role of Women - Caretakers, Conscience, Farmers, Educators and Entrepreneurs, Global Volunteers. Available online: https://globalvolunteers.org.

Goebel, A. (2003). Women and sustainability: What kind of theory do we need? Canadian Woman Studies, 23(1), 77-84.

Greco, A. \& de Jong, G. (2017) Sustainable entrepreneurship: definitions, themes and research gaps. Working paper series 1706-CSE, University of Groningen.

Gupta, V.K., Turban, D.B., Wasti, S.A., \& Sikdar, S. (2009). The Role of Gender Stereotypes in Perceptions of Entrepreneurs and Intentions to Become an Entrepreneur. Entrepreneurship Theory and Practice, 33(2), 397-417.

Hall, C.M., \& Williams, A.M. (Eds.). (2019). Tourism and Innovation. New York: Routledge.

Hallak, R. Brown, N. \& Lindsay, N.J. (2013). Examining tourism SME owners' place attachment, support for community and business performance: the role of enlightened self-interest model. Journal of Sustainable Tourism, 21(5), 658-678.

Hesselbarth, C., \& Schaltegger, S. (2014). Education future change agents for sustainability-learnings from the first sustainability management master of business administration. Journal of Cleaner Production, 62, 24-36.

Joo, D., Woosnam, K.M., Strzelecka, M. \& Boley, B.B. (2019). Knowledge, empowerment, and action: testing the empowerment theory in a tourism context.. Journal of Sustainable Tourism, 28(1), 69-85.

Juul, M. (2015). The sharing economy and tourism: Tourist accommodation. European Parliamentary Research Service. Disponivel em: http://www. europarl. europa. eu/RegData/etudes/BRIE/2015/568345/EPRS_BRI (2015) 568345_EN. pdf. Acesso em, 26(05), 2016.

Kassinis, G, Panayiotou, A., Dimou, A. \& Katsifaraki, G. (2016). Gender and Environmental Sustainability: A Longitudinal Analysis. Corporate Social Responsibility and Environmental Management, 23, 399-412 
Kato, K. (2019). Gender and sustainability-exploring ways of knowing-an ecohumanities perspective. Journal of Sustainable Tourism, 27(7), 939-956.

Keh, H. T., Der Foo, M., \& Lim, B. C. (2002). Opportunity evaluation under risky conditions: The cognitive processes of entrepreneurs. Entrepreneurship Theory and Practice, 27(2), 125-148.

Kepler, E. \& Shane, S. (2007), Are Male and Female Entrepreneurs Really That Different? US Small Business Administration, Office of Advocacy, Washington DC.

Kimbu, A.N. \& Ngoasong, M.Z. (2016). Women as vectors of social entrepreneurship. Annals of Tourism Research, 60, 63-79.

Koe, W.L., Omar, R. \& Majid, I.A. (2014). Factors associated with propensity for sustainable entrepreneurship. Procedia - Social and Behavioral Sciences, 130, 65-74.

Koellinger, P., Minniti, M. \& Schade, C. (2013). Gender differences in entrepreneurial propensity. Oxford Bulletin of Economics and Statistics, 75(2), 213-234.

Kokkranikal, J., \& Morrison, A. (2002). Entrepreneurship and sustainable tourism: The houseboats of Kerala. Tourism and Hospitality Research, 4(1), 7-20.

Kollmann, T., Stöckmann, C., \& Kensbock, J.M. (2017). Fear of failure as a mediator of the relationship between obstacles and nascent entrepreneurial activity-An experimental approach. Journal of Business Venturing, 32(3), 280-301.

Kraft, P., Rise, J., Sutton, S. \& Røysamb, E. (2005) Perceived difficulty in the theory of planned behaviour: Perceived behavioural control or affective attitude? British Journal of Social Psychology, 44, 479-496.

Kuckertz, A., \& Wagner, M. (2010). The influence of sustainability orientation on entrepreneurial intentions-Investigating the role of business experience. Journal of Business Venturing, 25(5), 524539.

Kwaramba, H.M., Lovett, J. C., Louw, L., \& Chipumuro, J. (2012). Emotional confidence levels and success of tourism development for poverty reduction. Tourism Management, 33, 885-894;

Landon, A.C., Woosnam, K.M., \& Boley, B.B. (2018). Modeling the psychological antecedents to tourists' pro-sustainable behaviors: An application of the value-belief-norm model. Journal of Sustainable Tourism, 26(6), 957-972.

Li, L. (2008). A review of entrepreneurship research published in the hospitality and tourism management journals. Tourism Management, 29(5), 1013-1022. 
Marlow, S. \& Patton, D. (2005). All Credit to Men? Entrepreneurship, Finance, and Gender. Entrepreneurship Theory and Practice, 29(6), 717-735.

Marlow, S. \& Swail, J. (2014). Gender, risk and finance: why can't a woman be more like a man?" Entrepreneurship and Regional Development, 26, 80-96.

Marlow, S. (1997). Self-employed women- new opportunities, old challenges? Entrepreneurship and Regional Development, 9(3), 199-210.

Mattis, M. C. (2004). Women entrepreneurs: out from under the glass ceiling. Women in Management Review, 19(3), 154-163

Minniti, M., Arenius, P. \& Langowitz, N. (2005), 2004 Global Entrepreneurship Monitor Special Topic Report: Women and Entrepreneurship, Center for Women's Leadership at Babson College, Babson Park, MA.

Moreno-Alarcón, D. A. \& Cole, S. (2019). No sustainability for tourism without gender equality. Journal of Sustainable Tourism, 27(7), 903-919.

Ngoasong M.Z. \& Kimbu A. N. (2019). Why Hurry? The Slow Process of High Growth in Women-Owned Businesses in a Resource-Scarce Context. Journal of Small Business Management, 57(1), 40-58.

Nikraftar, T., \& Hosseini, E. (2016). Factors affecting entrepreneurial opportunities recognition in tourism small and medium sized enterprises. Tourism Review, 71(1), 6-17.

Nowiński, W., Haddoud, M.Y., Lančarič, D., Egerová, D., \& Czeglédi, C. (2019). The impact of entrepreneurship education, entrepreneurial self-efficacy and gender on entrepreneurial intentions of university students in the Visegrad countries. Studies in Higher Education, 44(2), 361-379.

Outsios, G. \& Farooqi, S.A. (2017). Gender in sustainable entrepreneurship: evidence from the UK. Gender in Management: An International Journal, 32(3), 183-202.

Peeters, L.W.J. \& Ateljevic, I., 2009, Women Empowerment Entrepreneurship Nexus in Tourism: Processes of Social Innovation, in Ateljevic, J. e Page, S. J., (eds.) Tourism and Entrepreneurship: International Perspectives, Elsevier, Burlington, pp. 75-90.

Ploum, L., Blok, V., Lans, T., \& Omta, O. (2018). Toward a validated competence framework for sustainable entrepreneurship. Organization \& environment, 31(2), 113-132.

Pritchard, A., \& Morgan, N. (2017). Tourism's lost leaders: Analysing gender and performance. Annals of Tourism Research, 63, 34-47.

Reid, G.C., \& Smith, J.A. (2002). How do venture capitalists handle risk in high technology ventures?. Performance Measurement and Management Control, 12, 361-79. 
Roomi, M.A., Harrison, P. \& Beaumont-Kerridge, J. (2009). Women-owned small and medium enterprises in England analysis of factors influencing the growth process. Journal of Small Business and Enterprise Development, 16(2), 270-288.

Rowe, G. \& Wright, G. (2001). Differences in expert and lay judgements of risks: myth or reality? Risk Analysis 21(2), 341-356.

Santero-Sanchez, R., Segovia-Pérez, M., Castro-Nuñez, B., Figueroa-Domecq, C., \& Talón-Ballestero, P. (2015). Gender differences in the hospitality industry: A job quality index. Tourism Management, 51, 234-246.

Santillo, D. (2007). Reclaiming the definition of sustainability. Environmental Science and Pollution Research - International, 14, 60-66.

Scheyvens, R. (2000). Promoting women's empowerment through involvement in ecotourism: Experiences from the Third World. Journal of Sustainable Tourism, 8(3), 232-249.

Sexton, D. \& Bowman-Upton, N. (1990), "Female and male entrepreneurs: psychological characteristics and their role in gender-related discrimination", Journal of Business Venturing, 5(1), 29-36.

Shaw, G.J., \& Williams, A.M. (1999). Tourism Entrepreneurship: The Role of Small Business in British Coastal Resorts. Wirtschaftsfaktor Tourismus, Münster, Selbstverlag des Instituts für Geographie der Westfälischen Wilhelms-Universität Münster, 25-31.

Shepherd, D.A., \& Patzelt, H. (2011). The new field of sustainable entrepreneurship: Studying entrepreneurial action linking "what is to be sustained" with "what is to be developed". Entrepreneurship Theory and Practice, 35(1), 137-163.

Thompson, B.S., Gillen, J., \& Friess, D.A. (2018). Challenging the principles of ecotourism: insights from entrepreneurs on environmental and economic sustainability in Langkawi, Malaysia. Journal of Sustainable Tourism, 26(2), 257-276.

Truong, D., Liu, R.X., \& Yu, J.J. (2020). Mixed methods research in tourism and hospitality journals. International Journal of Contemporary Hospitality Management, 32(4),1563-1579.

UN Women (2014), World survey on the role of women in development, UN Women, New York (online). Available online: www.unwomen.org.

UN World Tourism Organization (2019). Global Report on Women in Tourism 2019. Madrid: WTO.

Vujko, A., Tretiakova, T.N., Petrović, M.D., Radovanović, M., Gajić, T., \& Vuković, D. (2019). Women's empowerment through self-employment in tourism. Annals of tourism research, 76(C), 328-330. 
Wachholz, S. (2011). Ecofeminism. In Deen K. Chatterjee (ed.). Encyclopedia of Global Justice, 289290.

Walls, J.L., Berrone, P., \& Phan, P.H. (2012). Corporate governance and environmental performance: is there really a link? Strategic Management Journal, 33(8), 885-913.

Williams, A.M., \& Baláž, V. (2015). Tourism risk and uncertainty: Theoretical reflections. Journal of Travel Research, 54(3), 271-287.

Williams, A.M., Rodríguez Sánchez, I., \& Škokić, V. (2020). Innovation, Risk, and Uncertainty: A Study of Tourism Entrepreneurs. Journal of Travel Research, https://doi.org/10.1177/0047287519896012

Wilson, F., Kickul, J. \& Marlino, D. (2007). Gender, Entrepreneurial Self-Efficacy, and Entrepreneurial Career Intentions: Implications for Entrepreneurship Education. Entrepreneurship Theory and Practice 31(3), 387-406.

Zahra, S.A, Wright, M. \& Abdelgawad, S.G. (2014). Contextualization and the advancement of entrepreneurship Research. International Small Business Journal, 32(5), 479-500.

Zampetakis, L.A., Bakatsaki, M., Kafetsios, K., \& Moustakis, V.S. (2016). Sex differences in entrepreneurs' business growth intentions: an identity approach. Journal of Innovation and Entrepreneurship, 5(1), 29.

Zhang, C.X., Kimbu, A.N., Lin, P. \& Ngoasong, M.Z. (2020), Guanxi influences on women intrapreneurship. Tourism Management, 81. https://doi.org/10.1016/j.tourman.2020.104137 


\section{Appendices}

\section{Appendix 1: Questionnaire Design}

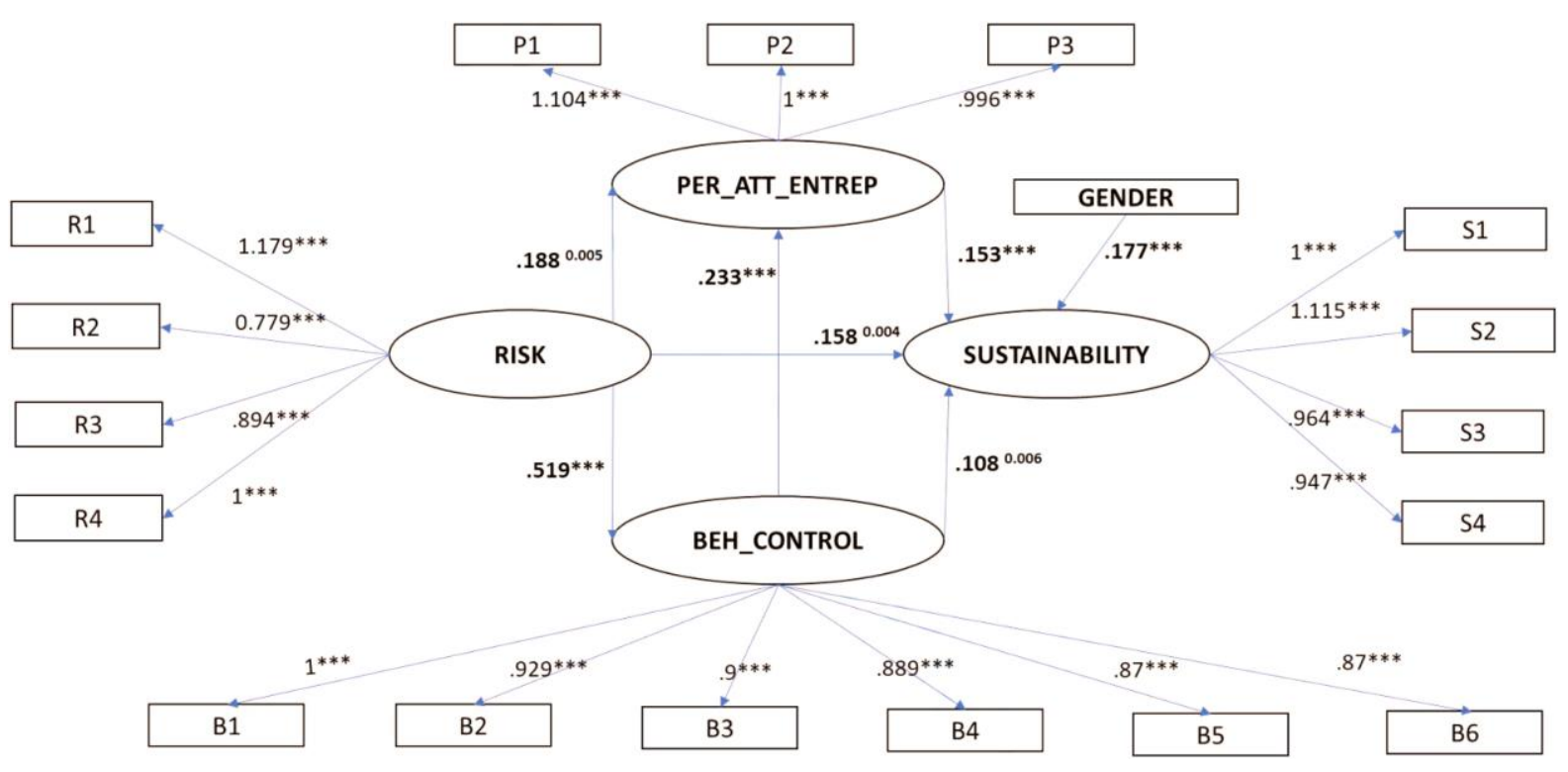

Figure A1. Structural path model

\section{ENTREPRENEURIAL INTENTION}

Are you, alone or with others, currently the owner of a business you help manage, self-employed, or selling any goods or services to others? Yes / No Are you, alone or with others, currently trying to start a new business, including any self-employment or selling any goods or services to others? Yes / No

You are not an entrepreneur yet, but how well do the following periods describe your potential interest in becoming an entrepreneur in the future?

GEM (2019), Costa et al. (2013), and Kollmann et al. (2017)

GEM (2019), Costa et al. (2013), and Kollmann et al. (2017)

Authors

SUSTAINABILITY (5 point Likert scale) (Coefficient Alphas $=0.898)$. Please value your level of agreement with the following statements on a scale from "Completely disagree" (1) to "Completely agree" (5)

Environmental problems are one of the biggest challenges for our society (S1)

Corporate social responsibility should be part of the foundations of each

Kuckertz and Wagner (2010) company (S2)

The environmental performance of a company will be considered more and more by financial institutions, in the future (S3)

Firms should take a leading role in the field of sustainability (S4)

Kuckertz and Wagner (2010)

Firms that care and are environmentally and socially sustainable have advantages in recruiting and retaining qualified employees (S5)

Kuckertz and Wagner (2010)

Kuckertz and Wagner (2010)

Kuckertz and Wagner (2010)

RISK (5 point Likert scale) (Coefficient Alphas $=0.898$ ). Please compare yourself to your best friends and rate your abilities on a scale from "Certainly Not" (1) to "Certainly Yes"

I adapt more flexibly to new situations than my friends (R1)

I manage my problems better than my friends (R2)

I would adapt better to changing living conditions than my friends (R3)

I am willing to take more risks than my friends (R4)

Williams and Baláž (2015)

Williams and Baláž

(2015)

Williams and Baláž, (2015)

Williams and Baláž, (2015) 
PERCEIVED ATTITUDE TOWARDS ENTREPRENEURSHIP (PAE) (5 point Likert scale) (Coefficient Alphas = 0.848). Please, answer to the following questions about your perception of entrepreneurship on a scale from "Completely disagree" (1) to "Completely agree" (5)

If I had the opportunity and resources, l'd like to start a firm (P1)

Being an entrepreneur would entail great satisfaction for me (P2)

Zampetakis et al. (2016)

Among various options, I would rather be an entrepreneur (P3)

Zampetakis et al. (2016)

Being an entrepreneur implies more advantages than disadvantages (P4)

Zampetakis et al. (2016)

PERCEIVED BEHAVIOURAL CONTROL (BC) (5 point Likert scale) (Coefficient Alphas = 0.961). To what extent are you able to effectively perform the following tasks: on a scale from "Not effectively at all" (1) to "Completely effectively" (5)

Creating and putting into operation a new venture (B1)

(Jaén et al., 2013)

Interacting with key people to raise capital to create a new venture (B2)

Jaén et al (2013)

Recognising opportunities in the market for new products and/or services

Jaén et al (2013)

(B3)

Negotiating and maintaining favourable relationships with potential investors

Jaén et al (2013) and banks (B4)

Keeping the new-venture creation process under control (B5)

Jaén et al (2013)

Defining your business idea and a new business strategy (B6)

Jaén et al (2013)

Having a successful business (B7)

Jaén et al $(2013$

\section{Appendix 2. Participants in interviews}

\begin{tabular}{lllll}
\hline Num. & Code & Sex & Age & \multicolumn{1}{c}{ Tourism industry } \\
1 & WomENt_01 & Women & $30-40$ & Consultancy \\
2 & WomENt_02 & Women & $40-50$ & Tourism intermediaries \\
3 & MenENt_01 & Men & $50-60$ & Consultancy \\
4 & WomENt_03 & Women & $30-40$ & Tourism intermediaries \\
5 & WomENt_04 & Women & $30-40$ & Tourism intermediaries \\
6 & MenENt_02 & Men & $40-50$ & Hotels and accommodation \\
7 & WomENt_05 & Women & $40-50$ & Hotels and accommodation \\
8 & WomENt_06 & Women & $40-50$ & Hotels and accommodation \\
9 & MenENt_03 & Men & $40-50$ & Consultancy \\
10 & MenENt_04 & Men & $40-50$ & Hotels and accommodation \\
11 & WomENt_07 & Women & $40-50$ & Hotels and accommodation \\
12 & WomENt_08 & Women & $40-50$ & Consultancy \\
13 & MenENt_05 & Men & $30-40$ & Tourism intermediaries \\
14 & WomENt_09 & Women & $30-40$ & Tourism intermediaries \\
15 & MenENt_06 & Men & $40-50$ & Consultancy \\
16 & WomENt_10 & Women & $30-40$ & Food and beverage \\
17 & MenENt_07 & Men & $30-40$ & Hotels and accommodation \\
18 & MenENt_08 & Men & $30-40$ & Transportation \\
19 & MenENt_09 & Men & $50-60$ & Hotels and accommodation \\
\hline
\end{tabular}

Appendix 3 
Following Dayour et al. (2019) factor correlations, loadings, model fit indices, as well as validity and reliability were estimated. Four constructs (Sustainability, Risk, PAE, BC) and one control variable (Gender) were included in the proposed model. Items with loadings below 0.5 were removed (Dayour et al., 2019), Boley et al., 2014; Filieri et al., 2015). Table A1 shows how the included items loaded significantly between 0.551 and 0.806 which is indicative that the interrelationships between items and associated constructs were high. In addition, and for internal consistency of the measurements, the Cronbach's alpha values were checked against the lower limit of 0.7 . Values exhibit adequate internal consistency.

Table A1. Descriptive and CFA statistics for each item.

\section{Sustainability}

S1 (Environmental problems are one of the biggest challenges for our society)

S2 (Corporate social responsibility should be part of the foundations of each company)

S3 (The environmental performance of a company will be considered more and more by financial institutions, in the future)

S4 (Firms should take a leading role in the field of sustainability) Risk

R1 (I adapt more flexibly to new situations than my friends)

Factor loading
Cronbach's alpha

R2 (I manage my problems better than my friends)

$\begin{array}{lll}0.747 & 4.45 \quad 0.799\end{array}$

$0.772 \quad 4.24 \quad 0.799$

$0.634 \quad 4.10 \quad 0.799$

0.687

4.36

0.799

R3 (I would adapt better to changing living conditions than my friends)

R4 (I am willing to take more risks than my friends)

\subsection{2}

3.78

0.747

0.551

3.61

0.747

0.621

3.67

0.747

\section{Attitude towards entrepreneurship (PAE)}

P1 (If I had the opportunity and resources, I'd like to start a firm)

P2 (Being an entrepreneur would entail great satisfaction for me)

0.641

3.53

0.747

P3 (Among various options, I would rather be an entrepreneur)

Perceived behavioural control (BC)

B1 (Creating and putting into operation a new venture)

0.781

4.20

0.817

0.806

4.02

0.817

0.736

3.66

0.817

B2 (Interacting with key people to raise capital to create a new venture)

B3 (Recognising opportunities in the market for new products and/or services)

B4 (Negotiating and maintaining favourable relationships with potential investors and banks)

$\begin{array}{lll}0.760 & 3.31 & 0.858 \\ 0.643 & 3.31 & 0.858\end{array}$

B5 (Keeping the new-venture creation process under control)

0.746

3.42

0.858

B6 (Defining your business idea and a new business strategy)

0.662

3.25

0.858

The adequacy of the model regarding its ability to mirror variance and covariance of the dataset was validated using the goodness-of-fit in CFA (Duffy et al. 2015; Dayour et al. (2019). Results of the CFA show that fit indices fall between suggested thresholds (PCMIN/DF $=2.570 ; \mathrm{CFI}=0,941$; RMSE $=$ $0.054 ; \mathrm{NFI}=0.908$ ). According to the results in Table A2 only Risk violates the test of discriminant and convergent validity, with an AVE of 0.444 (44.4\%). Although this might be a limitation, other studies (e.g. Boley et al., 2014) confirm the possibility to use this construct with a lower validity when there is strong precedence in the use of those items (e.g. Landon et al., 2018) and adequate factor loading and construct reliability are shown; also, the measurement model, including this construct, demonstrated 
acceptable fit, while modification indices did not reveal mechanisms for improvement (Landon et al., 2018).

Table A2. Convergent and discriminant validity.

\begin{tabular}{lcccccc}
\hline & CR & AVE & Risk & Sustain & Per_Att_Entrep & Beh_Control \\
Risk & 0.757 & 0.444 & $\mathbf{0 . 6 6 6}$ & & & \\
Sustainability & 0.803 & 0.507 & $0.272^{\star * *}$ & $\mathbf{0 . 7 1 2}$ & & \\
PAE & 0.818 & 0.601 & $0.268^{* * *}$ & $0.286^{* * *}$ & $\mathbf{0 . 7 7 5}$ & \\
BC & 0.86 & 0.507 & $0.383^{* * *}$ & $0.282^{* * *}$ & $0.336^{* * *}$ & $\mathbf{0 . 7 1 2}$ \\
\hline
\end{tabular}

Following the measurement model, the hypothesized relationships among constructs were tested using structural equation modelling (Figure A1). Co-variances were estimated for the four exogenous latent variables, and the outcome variables measuring intent, respectively.

The calculation of the $\mathrm{R}$ square show how the independent variables explain $17 \%$ of the dependent variable. The model shows a positive impact of the four exogeneous variables (three latent variables and one control variable). Results (Table A3) confirm that the interest in sustainability within entrepreneurship was jointly predicted by Gender, and specifically by being a woman $(\beta=0.177$; $p<0.000)(H 1)$, Risk acceptance $(\beta=0.158 ; p<0.000)(H 4 a)$, positive perception about their $B C$ $(\beta=0.108 ; p<0.006)(\mathrm{H} 3 a)$ and a positive PAE as a career $((\beta=0.153 ; p<0.000)(\mathrm{H} 2)$. Hypothesis testing of the relations amongst variables have also been confirmed. A highly gendered variable, Risk, has a positive impact on the student's perception of their $B C(\beta=0.519 ; p<0.000)(H 4 b)$ and their PAE $(\beta=0.188 ; p<0.005)(H 4 c)$. Furthermore, $B C$ has a positive impact on their $\operatorname{PAE}(\beta=0.233 ; p<0.000)$ $(\mathrm{H} 3 \mathrm{~b})$.

Table A3. Hypothesis relationships between constructs and observed relationship from the SEM.

\begin{tabular}{|c|c|c|c|c|}
\hline Hypothesis & Hypothesized relationship & $\begin{array}{c}\text { Beta } \\
\text { coefficient }\end{array}$ & $p$ & $\begin{array}{l}\text { Support to } \\
\text { hypothesis }\end{array}$ \\
\hline $\mathrm{H} 1$ & $\begin{array}{l}\text { H1. Women are more interested in sustainability in } \\
\text { entrepreneurship in tourism; Sustaina <--- COgender }\end{array}$ & 0.177 & *** & YES \\
\hline $\mathrm{H} 2$ & $\begin{array}{l}\text { H2. Perceived attitude towards entrepreneurship (the } \\
\text { capacity to identify business opportunities and } \\
\text { become an entrepreneur) impacts positively on the } \\
\text { importance attached to sustainability in } \\
\text { entrepreneurship; Sustaina <--- PAE }\end{array}$ & 0.153 & & YES \\
\hline $\mathrm{H} 3 \mathrm{a}$ & $\begin{array}{l}\text { H3a. Higher BC impacts positively on the importance } \\
\text { attached to sustainability in entrepreneurship; } \\
\text { Sustaina <--- BC }\end{array}$ & 0.108 & 0.006 & YES \\
\hline $\mathrm{H} 3 \mathrm{~b}$ & $\begin{array}{l}\text { H3b, Higher BC has a positive impact on having a PA; } \\
\text { PAE<--- BC }\end{array}$ & 0.233 & $* * *$ & YES \\
\hline $\mathrm{H} 4 \mathrm{a}$ & $\begin{array}{l}\text { H4a. The higher the risk acceptance the greater the } \\
\text { importance attached to Sustainability in } \\
\text { Entrepreneurship; Sustaina <--- Risk }\end{array}$ & 0.158 & $* * *$ & YES \\
\hline $\mathrm{H} 4 \mathrm{~b}$ & $\begin{array}{l}\text { H4b. Higher risk acceptance has a positive impact on } \\
\text { a positive personal perception of BC; } B C<--- \text { Risk }\end{array}$ & 0.519 & $* * *$ & YES \\
\hline$-14 c$ & $\begin{array}{l}\text { H4c. Higher risk acceptance has a positive impact on } \\
\text { a positive personal perception of PAE; PAE <--- Risk }\end{array}$ & 0.188 & 0.005 & YES \\
\hline
\end{tabular}

